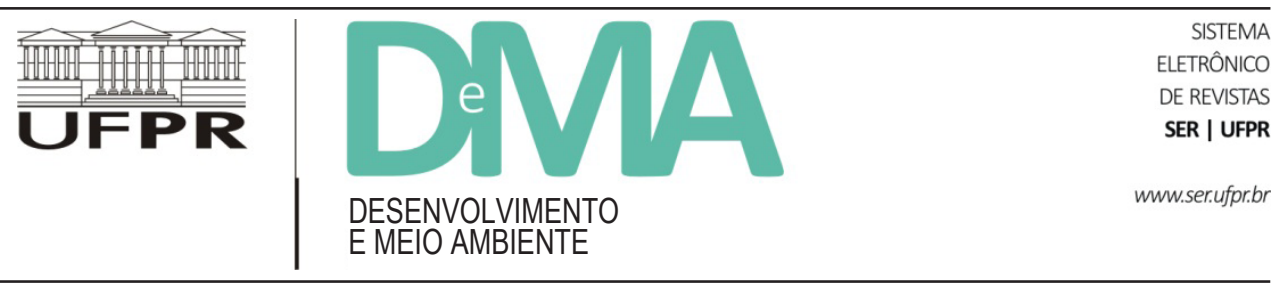

\title{
A política pesqueira no Brasil (2003-2011): a escolha pelo crescimento produtivo e o lugar da pesca artesanal ${ }^{1}$
}

\section{Fisheries Policy in Brazil (2003-2011): the Choice for Production Growth and the Place of Artisanal Fisheries}

\author{
Natália Tavares de AZEVEDO ${ }^{1,2^{*}}$, Naína PIERRI ${ }^{1,2}$ \\ ${ }^{1}$ Centro de Estudos do Mar (CEM), Universidade Federal do Paraná (UFPR), Pontal do Sul, PR, Brasil. \\ ${ }^{2}$ Programa de Pós-Graduação em Meio Ambiente e Desenvolvimento (PPGMADE), Universidade Federal do Paraná (UFPR), Curitiba, PR, Brasil. \\ *E-mail de contato: natytav@yahoo.com.br
}

Artigo recebido em 28 de fevereiro de 2014, versão final aceita em 8 de agosto de 2014.

RESUMO Este artigo analisa a política pesqueira nacional entre 2003 e 2011, visando identificar o lugar da pesca artesanal. A eleição do Partido dos Trabalhadores, sua base popular e o programa de governo anunciado criaram expectativas de que este subsetor seria, pela primeira vez, especialmente atendido e favorecido. Mais tarde, evidências empíricas, a visão crítica surgida nas organizações autônomas de pescadores, e a falta de conhecimento sistemático e de conjunto motivaram esta pesquisa. Para tanto, além da revisão bibliográfica, foram analisados documentos e dados obtidos nas instituições envolvidas, entrevistaram-se informantes-chave, e se fez observação direta e participante. Os resultados mostram que a política pesqueira federal do período favoreceu mais a aquicultura que a pesca extrativa e, dentro desta, mais a pesca industrial que a artesanal. Por sua parte, as medidas dirigidas ao subsetor artesanal, apesar de representarem diversas melhoras, foram insuficientes para fortalecê-lo e reverter a vulnerabilidade socioambiental de suas comunidades.

Palavras-chave: política pesqueira; pesca artesanal; justiça ambiental.

ABSTRACT This paper examines the Brazilian fisheries policy between 2003 and 2011, aiming at identifying the place of artisanal fisheries. The election of the Workers Party (Partido dos Trabalhadores), its popular basis and the announced government program created expectations that this subsector would be, for the first time, especially favored. Later, empirical evidence, the critical view that arose in the autonomous organizations of artisanal fishermen and fisherwomen, and the lack of systematic knowledge motivated this research. Therefore, in addition to the literature review, we analyzed documents and data from the institutions involved, interviewed key informants, as well as made direct and participant observation. The measures directed at the artisanal subsector, despite representing several improvements, were insufficient to strengthen it and reverse the environmental vulnerability of their communities.

Keywords: fisheries policy; artisanal fisheries; environmental justice.

\footnotetext{
${ }^{1}$ Essa pesquisa contou com financiamento do Instituto HSBC Solidariedade, além da bolsa de doutorado concedida pelo CNPq.
} 


\section{Introdução}

$\mathrm{Na}$ sociedade de mercado, intrinsecamente desigual, as responsabilidades de causar e enfrentar a crise ambiental são socialmente desiguais. Nesse contexto, a situação de imposição desproporcional de impactos e riscos ambientais aos mais pobres tem sido denominada de injustiça ambiental e a reversão destas configuram-se como situações de justiça ambiental (Acselrad et al., 2009). As pessoas e grupos socialmente mais vulneráveis são os mais expostos a situações de risco ou estresse, os mais sensíveis a essas, e os que têm menor capacidade de se recuperar. Assim, considera-se vulnerabilidade socioambiental a coexistência, cumulatividade ou sobreposição espacial de situações de vulnerabilidade social e de situações de exposição a risco e/ou degradação ambiental (Alves, 2009).

Um dos setores que no Brasil, como no mundo todo, está submetido a processos crescentes de vulnerabilização socioambiental é o dos pescadores artesanais, por combinar pobreza, condições precárias de vida, e riscos específicos derivados, em grande parte, de problemas ambientais que diminuem sua resiliência e capacidade adaptativa (FAO, 2009). Essas condições e elementos caracterizam uma clara situação de injustiça ambiental: esses pescadores e comunidades são vítimas principais de problemas ambientais dos quais não são responsáveis (ou não são os principais responsáveis) ampliando assim sua vulnerabilidade social (Vasconcellos et al., 2007).

Essa crescente condição de vulnerabilidade dos pescadores artesanais e de suas comunidades se dá, entre outros elementos, em decorrência das formas de desenvolvimento do setor pesqueiro ocorrida durante o século XX, especialmente a partir da década de 1950. Nesse período, a atividade pesqueira em todo o mundo experimentou um acelerado processo de crescimento, com o desenvolvimento da pesca industrial e o aumento do poder de pesca das embarcações, levando à sobre-explotação de diversas espécies e ao reconhecimento da crise dos recursos pesqueiros como uma das facetas da crise ambiental (Diegues, 1983; Clausen e Clark, 2005).

Nesse cenário, os Estados e governos tiveram e têm um papel fundamental, pois estes atuaram proporcionando fortes investimentos e subsídios que impulsio- naram tal desenvolvimento. Por outro lado, as medidas de ordenamento e gestão dos recursos adotadas foram incipientes, resultando no esgotamento dos recursos pesqueiros, na progressiva marginalização da pesca artesanal e, posteriormente, em um acelerado desenvolvimento da aquicultura, gerando novos conflitos em torno do uso dos espaços aquáticos.

Essa conjuntura também se reproduziu no Brasil, onde entre as décadas de 60 e 80 do século $\mathrm{XX}$ as políticas setoriais se centraram em financiamentos e incentivos fiscais, o que contribuiu à sobrecapacidade de pesca e à redução dos estoques (Abdallah e Sumaila, 2007). Nos anos 1990, depois de uma primeira fase centrada na conservação dos recursos, a gestão, ainda que com alguns avanços de ordenamento, se caracterizou por contradições entre as políticas de promoção e de conservação e pela ineficácia. A pesca artesanal nunca foi objeto principal das preocupações do governo (Dias Neto, 2003).

Em 2003, durante o primeiro governo do Partido dos Trabalhadores, na gestão do Presidente Luis Inácio Lula da Silva, foi criada a Secretaria Especial de Aquicultura e Pesca. Em 2009, essa Secretaria Especial foi transformada em Ministério e foi aprovada e sancionada uma nova lei de pesca, iniciando assim uma nova etapa na política pesqueira. O discurso e a base popular do governo criaram a expectativa de desenvolvimento de políticas que favoreceriam substancialmente as classes populares, o que, no âmbito do setor pesqueiro, representaria um maior atendimento às demandas da pesca artesanal. Desta forma, este artigo visa apresentar uma análise da política do governo federal dirigida ao setor pesqueiro, observando como equaciona as dimensões econômica, ecológica e social da sustentabilidade e qual subsetor resulta mais favorecido. Neste artigo, são apresentados os principais resultados da pesquisa com ênfase nos aspectos econômicos e sociais e como se articularam na política sob análise.

Além desta introdução, este texto está composto por outras cinco seções. Na seção 2, apresentam-se o enfoque teórico metodológico da pesquisa e os procedimentos metodológicos adotados. Na seção 3, são abordados os antecedentes da pesquisa, ou seja, faz-se um breve histórico das políticas que antecederam o período analisado e, em linhas gerais, suas consequências para o 
setor pesqueiro. Na seção 4, discutem-se as mudanças institucionais que ocorreram no período sob análise. No item 5, destacam-se o enfoque das políticas no crescimento produtivo e os protagonistas eleitos para esse crescimento e por fim, na seção 6, apresenta-se o lugar ocupado pela pesca artesanal no conjunto das políticas empreendidas entre 2003 e 2011.

\section{Enfoque teórico-metodológico e técnicas de pesquisa}

Tomou-se como orientação teórica geral o enfoque socioambiental histórico-crítico que, dito de forma simplificada, interpreta como causa última da crise ambiental atual a economia de mercado, cuja lógica de maximização de lucro conduz a um uso ilimitado de recursos e de geração de dejetos, ao mesmo tempo que possui limites intrínsecos para a superação da pobreza (Acselrad e Leroy, 1999, Foladori; 2001a).

Por outro lado, implica em se compreender o Estado como parte da dimensão superestrutural que possui uma autonomia relativa frente à base econômica, cujas instituições constituem materializações e pontos nodais das relações de poder entre as diferentes classes e frações de classe, ideologias e projetos societários (Therborn, 1989). Assim, as políticas públicas são entendidas como as ações do Estado, implantando um projeto de governo por meio de programas e ações voltadas a setores específicos da sociedade, onde, além de reproduzir o sistema em geral, beneficia a uns em detrimento de outros, dependendo da ideologia do governo de turno e das pressões que este sofre por parte dos diferentes setores econômicos e políticos que disputam seu apoio (Hofling, 2001).

Metodologicamente, iniciou-se por identificar o âmbito de cada medida instrumentada pelo governo e foram analisadas as suas implicações ou consequências para cada uma das dimensões do desenvolvimento sustentável: econômica, ecológica e social. Já as ênfases presentes na política pesqueira e o seu significado para a pesca artesanal se identificaram determinando, a partir do peso e efeitos imediatos e mediatos das medidas, a dimensão efetivamente privilegiada, assim como a forma em que esta subordina às outras (Foladori, 2001b; Pierri, 2001).
Em termos de fases e técnicas de pesquisa, iniciou-se por uma ampla revisão bibliográfica sobre os aspectos teóricos, históricos e de antecedentes de pesquisa pertinentes. Complementarmente, obtiveram-se documentos e dados sobre as políticas e sua aplicação nos sítios eletrônicos do Ministério de Pesca e Aquicultura (MPA), do Ministério do Planejamento, Orçamento e Gestão (MPOG) e do Ministério do Meio Ambiente (MMA), o que foi complementado com visitas a essas instituições onde se realizaram entrevistas com alguns técnicos e gestores e se solicitaram dados não disponíveis na internet. Também foram coletados dados junto aos sítios eletrônicos do Instituto Brasileiro do Meio Ambiente e Recursos Naturais Renováveis (IBAMA), do Ministério de Trabalho e Emprego (MTE) e no Portal Transparência Brasil, no qual são inseridos os gastos do governo por ano e por Ministério.

Realizaram-se entrevistas semiestruturadas para qualificar as informações obtidas por meio da coleta de dados secundários com gestores e técnicos do Ministério da Pesca e Aquicultura (MPA) e do Ministério do Meio Ambiente (MMA), visando compreender a atuação dos dois órgãos e os processos de formulação das políticas. Além disso, foram realizadas entrevistas com representantes do setor pesqueiro industrial, da aquicultura industrial e representantes de organizações de apoio à pesca artesanal, como o Conselho Pastoral dos Pescadores, de Pernambuco, e o Instituto Terramar, do Ceará, com a finalidade de reconhecer suas percepções acerca da política implementada pelo MPA.

Complementaram-se esses dados com observação participante em diversos encontros das organizações de pescadores artesanais entre os anos de 2010 e 2011, incluindo reuniões do Movimento dos Pescadores e Pescadoras Artesanais do Brasil (MPP) e da Articulação Nacional das Pescadoras (ANP). No ano 2010 foi realizada observação direta em reuniões do Conselho Nacional de Aquicultura e Pesca (CONAPE), fórum consultivo ligado ao Ministério da Pesca e Aquicultura, no encontro Aquapesca Brasil ocorrido em Itajaí, que reuniu representantes da pesca industrial e da aquicultura empresarial, e no I Encontro Nacional dos Territórios da Pesca e Aquicultura, no qual se reuniram representantes do Ministério da Pesca e Aquicultura e pescadores artesanais que participavam dessa política de descentralização. 
A organização da informação foi iniciada pela apresentação da situação da pesca e as políticas aplicadas por governos anteriores, com o intuito de compor a contextualização histórica necessária para a compreensão do período atual. Já para a análise dos dados referentes ao período 2003-2011, as medidas concretas foram organizadas segundo as dimensões da sustentabilidade: na econômica, foram abordadas as chamadas políticas de fomento dirigidas ao aumento da produção, tais como concessão de créditos, subsídios, isenções fiscais, investimentos em infraestrutura, pesquisa e desenvolvimento tecnológico; na dimensão social, foram abordadas as medidas dirigidas a melhorar a renda e condições de vida dos pescadores (renda, saúde, educação, previdência social, etc.); e na dimensão ecológica, foram observadas as medidas de gestão e conservação dirigidas à sustentação dos recursos pesqueiros e ecossistemas envolvidos.

\section{Antecedentes: os vaivéns das políticas prévias (1960-2003)}

Pautando-se nas produções recentes sobre a dimensão político-institucional da administração pesqueira no Brasil (Giulietti \& Assumpção, 1995; Abdallah, 1998; Dias Neto, 2003; Paiva, 2004; FAO Brasil, 2006, entre outros) identificaram-se três períodos com características distintas na organização institucional para a gestão da pesca no país prévios ao período analisado. Em que pese à diferença de análises entre os autores, elas correspondem: i) ao período de vigência do controle da pesca pela Superintendência do Desenvolvimento da Pesca entre os anos de 1962 e 1989; ii) ao período em que o Instituto Brasileiro do Meio Ambiente e dos Recursos Naturais Renováveis - IBAMA - ficou com a responsabilidade exclusiva da gestão das pescarias no Brasil entre 1989 e 1998; iii) ao período de divisão de competências entre o Ministério do Meio Ambiente - MMA e o Ministério da Agricultura e Abastecimento entre 1998 e 2003.

Entre 1962 e 1989, período que inclui o governo militar (1964-1985), o órgão responsável pelas políticas para o setor foi a Superintendência do Desenvolvimento da Pesca (SUDEPE), que implementou uma política desenvolvimentista, focada especialmente na pesca industrial, fazendo uso de incentivos fiscais e tributários amparados, entre outros, no Decreto $\mathrm{n}^{\circ} 227$ de 1967 (Brasil, 1967), além de medidas de crédito subsidiado para o setor. Segundo informações do relatório do Banco Nacional de Desenvolvimento Econômico (BNDE, 1975), que apresentava uma análise das ações empreendidas pelo órgão no fomento ao setor pesqueiro à época, essas iniciativas de utilização de instrumentos financeiros de estímulo às atividades pesqueiras foram gestadas no âmbito do convênio do governo brasileiro com a Organização das Nações Unidas para a Alimentação e Agricultura (FAO) com a formação do Programa de Pesquisa e Desenvolvimento Pesqueiro no Brasil (PDP). Ligados ao PDP foram também criados os Grupos Permanentes de Estudo (GPE), que tinham como função ordenar a pesca das principais espécies explotadas comercialmente (sardinhas, atuns, camarões, etc.), dos quais derivaram os primeiros instrumentos de comando e controle de caráter mais abrangente na gestão das pescarias, mas que se mostraram insuficientes para manter níveis sustentáveis de exploração dos recursos pesqueiros.

Nesse período efetivaram-se também algumas medidas modernizantes para a pesca artesanal - particularmente o financiamento de motores -, ainda que estas tenham ocupado um espaço muito pequeno no total das ações empreendidas (Diegues, 1988). No conjunto, essa política gerou, do ponto de vista econômico, o maior crescimento histórico contínuo da pesca extrativa, mas, do ponto de vista ambiental, gerou a sobrepesca dos principais recursos com destaque para o colapso da pesca da sardinha verdadeira (Sardinella brasiliensis) no início da década de 1990, que posteriormente apresentou recuperação (Abdallah, 1998; Dias Neto, 2003; Abdallah $\&$ Sumaila, 2007).

Considerando a conjuntura política e econômica do período de vigência da SUDEPE, pode-se dizer que as medidas adotadas para a pesca inscreveram-se dentro da orientação da atuação governamental do período, de caráter desenvolvimentista e no qual se aplicaram uma série de iniciativas de investimentos para a modernização do país, período que ficou conhecido como "milagre brasileiro" (Furtado, 1982). Como resultados dessas medidas de modernização, caracterizadas por Delgado (1985) como conservadoras, observou-se a ampliação da desigualdade social e o aumento da pobreza em todo o país (Furtado, 1982). 
Por fim, a crise dos recursos pesqueiros, somada às várias denúncias de malversação de fundos públicos e de corrupção, levou à extinção da SUDEPE (Dias Neto, 2003; Paiva, 2004; FAO Brasil, 2006).

Em 1989, já após a reabertura democrática e a promulgação da nova Constituição, as funções da SUDEPE foram atribuídas a uma instituição ambiental, o então recém-criado Instituto Brasileiro do Meio Ambiente e dos Recursos Naturais Renováveis (IBAMA), que depois veio a ser o principal braço executor do Ministério de Meio Ambiente, criado em 1992 (Dias Neto, 2003). Nesse período, que vai até 1998 , essa alocação da política pesqueira no órgão ambiental federal, somada à adoção geral de medidas neoliberais que inibiram certos investimentos públicos (Antunes, 2005; Acselrad, 2006), conduziu o foco para políticas conservacionistas. A atuação do IBAMA baseou-se fundamentalmente na conservação e preservação dos recursos pesqueiros, com poucas ações de incentivo ao desenvolvimento e fomento à atividade.

De acordo com Maneschy (1999), o enfoque do IBAMA estava na gestão e conservação dos recursos, e o desenvolvimento da atividade pesqueira estava fora do foco institucional. Sua principal tarefa era o controle da sobre-explotação dos recursos e o controle da pesca predatória, tanto artesanal quanto industrial. Ainda de acordo com Maneschy (1999), apesar do enfoque conservacionista da atuação do IBAMA no período, ela foi socialmente mais equilibrada do que a política exercida pela SUDEPE, uma vez que, se bem não buscou formas de desenvolver a pesca artesanal, também não ofereceu subsídios e facilidades à pesca industrial. Maneschy destaca ainda que naquele momento (1999) o IBAMA passava a tomar iniciativas no sentido da cogestão dos recursos (tratava, no caso, do Norte do país), alterando o viés top-down até então adotado na forma de controle da atividade. Assim, cortaram-se quaisquer incentivos para o desenvolvimento da atividade e foram criados diversos instrumentos de gestão pesqueira, visando limitar o esforço de pesca e proteger certas espécies.

O terceiro período se inicia em 1998 com a criação do Departamento de Pesca e Aquicultura (DPA) no interior do Ministério da Agricultura, que foi uma tentativa de retirar a tutela ambiental do setor e retomar a política desenvolvimentista. Abriu-se então um período de fortes conflitos institucionais entre o Ministério de Agricultura e o IBAMA, motivados pela divisão de competências na gestão e ordenamento dos recursos pesqueiros e pela retomada, ainda que incipiente, dos investimentos no setor pesqueiro, que, então, além de se dirigir principalmente à pesca industrial, também privilegiava a aquicultura empresarial, com ênfase no desenvolvimento da carcinicultura. Destaca-se nesse período o que Dias Neto (2003) chamou de a "divisão do indivisível", visto que, em relação à gestão dos recursos pesqueiros, cabia ao DPA a gestão dos recursos considerados subexplotados, e ao IBAMA a gestão dos recursos considerados sobre-explotados.

É pertinente salientar, como apontam Vasconcellos et al. (2007), que destarte a atuação de um órgão ambiental responsável pela gestão dos recursos pesqueiros, em especial dos sobre-explotados, durante mais de duas décadas, este não foi capaz de reverter tal situação, e o avanço nos planos de gestão dessas espécies foram incipientes.

A pesca artesanal ao longo desses três períodos não foi alvo de praticamente nenhuma ação por parte dos governos, que se centraram ora no desenvolvimento industrial do setor, ora na conservação e preservação dos recursos. Desta forma, a condição social dos pescadores artesanais, sua contribuição econômica e à produção de alimento, e a diversidade de suas formas culturais de vida estiveram fundamentalmente à margem das preocupações governamentais. Mais do que isso, o resultado das políticas desenvolvimentistas e conservacionistas, somado ao vazio de políticas substantivas para a pesca artesanal, determinaram que a maioria dos pescadores artesanais e suas comunidades ficassem em condições muito precárias de vida. Assim, eles se constituíram nas principais vítimas da crise dos recursos pesqueiros, sem ter sido os principais responsáveis de causá-la, ficando condenados ao empobrecimento e a enfrentar a concorrência desigual com a pesca industrial e a aquicultura empresarial e os conflitos derivados.

Com a eleição do Partido dos Trabalhadores e a assunção ao governo do Presidente Lula em 2003, esperava-se, então, que este atuasse favorecendo prioritariamente à pesca artesanal, que é responsável por mais 
da metade da produção pesqueira extrativa do país, pois ocupa diretamente cerca de 700 mil pessoas ${ }^{2}$, e cerca de 2 milhões de pessoas dependem dela (Vasconcellos et al., 2007).

\section{Mudanças institucionais: a centralização das funções no órgão setorial}

Conforme proposto durante o período de campanha eleitoral, por meio da Carta de Compromisso aos Pescadores, já no início do governo em 2003 foi criada a Secretaria Especial de Aquicultura e Pesca (SEAP) com status ministerial. Contudo, a SEAP herdou a mesma divisão de competências com os órgãos ambientais existentes no período do DPA/MAPA, mantendo conflitos institucionais na administração pesqueira (FAO Brasil, 2006).

O destaque no momento de criação da SEAP, mais do que na alteração das competências em relação à gestão dos recursos pesqueiros e do ordenamento aquícola, estava na criação de um órgão de nível hierárquico superior, em relação ao DPA/MAPA, para o fomento à atividade. No Caderno de Resoluções da $1^{\text {a }}$ Conferência Nacional de Pesca e Aquicultura (SEAP, 2003), a SEAP afirma seu papel como fomentador e sua ênfase na modernização da cadeia produtiva, postulando uma posição mais ativa do Estado "permitindo o controle da atividade e a agilidade no estabelecimento de políticas desenvolvimentistas (grifos nossos), garantindo dessa forma sua sustentabilidade" (SEAP, 2003, p.1).

Porém, a divisão de competências na gestão dos recursos entre a SEAP e IBAMA/MMA permanecia gerando problemas e conflitos. Nesse sentido, o governo brasileiro contou, para tratar da reorganização institucional para a gestão e desenvolvimento da pesca no país a fim de superar os impasses e conflitos, com um assessoramento técnico da Organização das Nações Unidas para a Alimentação e Agricultura (FAO Brasil, 2006). Em seu Relatório Técnico de Assessoramento apresentava três opções para solucionar o problema institucional: a criação de um Ministério, a criação de um novo Instituto (autarquia federal), e/ou a criação de uma agência reguladora com uma posição privilegiada para a criação do Ministério.

A primeira tentativa do governo de criação do Ministério da Pesca e Aquicultura se deu então com a Medida Provisória (MP) no 437 de 29 de julho de 2008 (Brasil, 2008). Contudo, a medida foi contestada tanto pela oposição no legislativo quanto internamente no governo, pois sua decisão não havia sido acordada em nível técnico, no qual não houve consenso, mas definida pela Casa Civil (Dias Neto, 2010).

A proposta de criação do Ministério da Pesca e Aquicultura, refutada enquanto MP, foi então transformada em projeto de lei, encaminhada em caráter de urgência e aprovada praticamente sem alterações ao texto original como a Lei 11.958 de 26 de junho de 2009 (Brasil, 2009a).

Uma das principais mudanças derivadas desse reordenamento institucional foi a primazia outorgada ao MPA nas funções de administração pesqueira e ordenamento aquícola, incorporando grande parte das atividades de monitoramento e controle definitivamente, como a estatística pesqueira. Assim, depois de anos de tensão e conflitos, a lei que transformou a SEAP em MPA estabeleceu que a fixação de normas e medidas para o ordenamento do uso dos recursos pesqueiros caberia ao MPA e ao MMA conjuntamente sob coordenação do MPA.

A atuação conjunta dos dois ministérios foi instituída pelo Decreto $\mathrm{n}^{\circ} 6.981$ de 13 de outubro de 2009 (Brasil, 2009b), que criou o Sistema de Gestão Compartilhada dos Recursos Pesqueiros e instituiu a Comissão Técnica de Gestão Compartilhada (CTGP) como órgão consultivo e coordenador do sistema de gestão, composto por representantes de cada ministério e coordenado por representante do MPA. Esse sistema foi regulamentado pela Portaria Interministerial MPA/MMA n ${ }^{\circ} 2$ de 13 de novembro de 2009 (Brasil, 2009c), que previa a formação de Comitês Permanentes de Gestão que deveriam ser órgãos colegiados compostos por membros do governo e da sociedade civil, tendo como incumbência produzir os planos de gestão para espécies ou áreas específicas. Até o momento, contudo, apresenta-se uma grande debilidade na capacidade de formação desses comitês.

\footnotetext{
${ }^{2}$ Atualmente, de acordo com o Registro Geral da Pesca realizado pelo MPA, existem nominalmente mais de 900 mil pescadores artesanais no país.
} 
Assim, o novo período é marcado não apenas pela retomada do fomento, mas também pela busca sistemática da centralização das funções de ordenamento no órgão setorial. Essa ampliação das competências institucionais no MPA, com perda para os órgãos ambientais, deve ser vista com cautela, uma vez que, enquanto compartilhavam competências, a SEAP se mostrou mais susceptível às pressões do setor em detrimento de uma postura de precaução, ou até mesmo, de oitiva das medidas postuladas pela área ambiental.

Isso se torna evidente, por exemplo, no caso da sardinha-verdadeira, uma das principais espécies capturadas pela frota industrial no país. No Plano de Gestão para o Uso Sustentável da Sardinha Verdadeira (IBAMA, 2011), atribuição do IBAMA de acordo com a Instrução Normativa MMA n ${ }^{\circ}$ 05/2004 (Brasil, 2004), os dados analisados pelos técnicos do órgão, a partir das informações a estes repassadas pela SEAP, demonstram que esta última concedeu permissões de pesca a embarcações que não poderiam integrar a frota, pois com a edição da Portaria no 96 de 1997 (Brasil, 1997), por parte do IBAMA, proibia-se o ingresso de novas embarcações nessa pescaria, a não ser em substituição a outra de mesmo porte.

Nos dados apresentados nesse documento, destaca-se ainda que embarcações foram substituídas por outras com maior poder de pesca, bem como que foram concedidas permissões alternativas para as embarcações da frota da sardinha atuarem sobre outras espécies que também têm esforço de pesca controlado, como a tainha, a corvina e a anchova, o que, de acordo com o documento, também era proibido, ainda que não especifique o ato normativo que estabelecia essa proibição. Essas permissões foram concedidas atendendo às demandas do setor industrial, que afirmava que nos períodos de defeso da sardinha ficava com a frota ociosa, o que inviabilizaria economicamente as empresas e os armadores (IBAMA, 2011).

Posteriormente, a concessão dessas permissões alternativas foi convalidada por Instruções Normativas criadas conjuntamente pelos dois Ministérios, embora o número de embarcações a receberem essas licenças tenha sido alvo permanente de conflito entre os técnicos do MPA e do IBAMA, tendo prevalecido, como no caso da captura da tainha no ano de 2010, a posição do MPA que autorizou 89 embarcações, enquanto a posição do
IBAMA apontava para o licenciamento de 60 (IBAMA, 2011).

Destaca-se que essas espécies - tainha, anchova, corvina - têm grande importância para a pesca artesanal na região sul, e a permissão para a frota industrial atuar sobre elas aumentou ainda mais os conflitos já existentes entre estes na região. Nesse aspecto, pode-se inferir que a ampliação das competências do órgão setorial tende a dar a dimensão econômica um peso maior do que à ecológica, pois é mais suscetível às pressões do setor produtivo. Apesar disso, não se pode dizer que o MPA atue sem o reconhecimento das limitações ambientais da atividade, mas sim que há conflitos entre as perspectivas ambiental e setorial sobre como e quanto se pode atuar sobre os recursos e garantir a sustentabilidade destes e do setor.

Os conflitos também existiam (e existem) em relação à aquicultura. Como já vinha ocorrendo anteriormente com o DPA/MAPA, à SEAP coube competências estabelecidas pelo Decreto ${ }^{\circ} 4.895$ de 25 de novembro de 2003 (Brasil, 2003), de cessão de uso das águas da união para fins de aquicultura bem como sua competência para a realização do ordenamento aquícola. No texto do Programa Nacional de Desenvolvimento da Maricultura em Áreas da União (SEAP, 2005a), a própria SEAP destacava os conflitos e polarização no entendimento em relação ao desenvolvimento da atividade dentro dos órgãos governamentais, destacando que uns enfocavam na dimensão econômica e outros na ecológica.

\begin{abstract}
Atualmente esta questão se encontra polarizada entre os que ressaltam os resultados econômicos e os que enfatizam os impactos ambientais, e apesar do setor ser enormemente diverso, há uma tendência de se generalizar a maricultura a partir de exemplos específicos, como a carcinicultura. As ações promovidas pelos órgãos ambientais têm se atido ao estabelecimento de procedimentos complexos e à criteriosa análise para a emissão de licenças ambientais para a atividade. Esta abordagem individual não tem garantido a sustentabilidade da maricultura e em alguns casos tem servido apenas para privar o país dos resultados sociais e econômicos que acompanham seu desenvolvimento (SEAP, 2005a, p.11).
\end{abstract}

Deve-se destacar também que a atividade aquícola deveria obedecer ao zoneamento ecológico-econômico 
realizado pelos Planos Nacional, Estaduais e Municipais de Gerenciamento Costeiro, porém muitos Estados ainda não têm uma legislação aprovada e efetiva que regule e ordene o uso dos espaços costeiros. Assim, segundo a Resolução $n^{\circ} 413$, do Conselho Nacional do Meio Ambiente de 26 de junho de 2009 (Brasil, 2009d), que regula o processo de licenciamento ambiental das atividades aquícolas, a não existência desses documentos não impede o licenciamento ambiental destes empreendimentos, o que, na prática, permite a liberação de áreas de cultivo sem o devido amparo em um processo de ordenamento territorial mais abrangente.

Outro debate que se travou em relação ao desenvolvimento da aquicultura nas águas da União, especialmente na zona costeira, diz respeito à competência entre os órgãos componentes do Sistema Nacional do Meio Ambiente (SISNAMA) para o licenciamento da atividade. Por um lado, entendia-se que, como se trata de áreas da União, caberia ao IBAMA realizar os procedimentos, por outro, postulava-se que os órgãos ambientais estaduais teriam competência para licenciar tais empreendimentos. A disputa se refere não apenas a uma questão de competências jurídicas, mas também ao entendimento de que os órgãos estaduais e municipais acabam por adotar critérios menos rigorosos para o procedimento de licenciamento, por estarem mais sujeitos às pressões políticas dos agentes econômicos na escala local, e que o licenciamento pelo IBAMA garantiria um controle mais rigoroso da atividade. Por fim, a referida resolução do CONAMA, que regula o licenciamento, definiu que os órgãos ambientais estaduais e municipais têm competência para o licenciamento da aquicultura.

Também em 2009, concomitante com a criação do Ministério, aprovou-se o novo marco legal para a pesca no país, por meio da Lei no 11.959 (Brasil, 2009e) que instituiu a Política Nacional para o Desenvolvimento Sustentável da Aquicultura e da Pesca. Esta marca a adoção, dentro do marco legal específico para o setor pesqueiro, do discurso do desenvolvimento sustentável, ou seja, visando compatibilizar crescimento econômico, cuidado ambiental e redução da pobreza. Esse novo marco legal representa um avanço significativo no que tange a Lei da Pesca anterior (Decreto ${ }^{\circ}$ 227/1967). Mantêm-se os instrumentos de comando e controle como os principais mecanismos de gestão da pesca, adicionando-se os princípios da participação social e da cogestão.

Entre os avanços trazidos pelo novo marco legal estão o estabelecimento de que o ordenamento deve considerar as peculiaridades a pesca artesanal e garantir sua permanência, bem como o reconhecimento de toda a cadeia produtiva na atividade pesqueira, o que fundamenta a garantia de direitos previdenciários de trabalhadores de toda a cadeia.

É necessário destacar, ainda, que a Nova Lei da Pesca traz definições imprecisas em relação às categorias que compõem o setor, ao prever que a pesca artesanal possa se realizar em regime de economia familiar ou de forma autônoma mediante regimes de parceria, com embarcações de pequeno porte. Ao mesmo tempo, define a pesca industrial como aquela realizada por pessoas físicas ou jurídicas, com pescadores empregados ou em regime de parceria por cotas-partes, com embarcação de pequeno, médio e grande porte. Porém, na lei se caracteriza as embarcações de pequeno porte como aquelas com até $20 \mathrm{AB}$, tamanho considerado por muitos pescadores e técnicos especializados além dos padrões para a pesca artesanal no país.

Como se vê, portanto, há uma sobreposição na definição, o que pode levar a que armadores da pesca se beneficiem de medidas moldadas para atender aos pescadores artesanais, como o registro na previdência em regime de economia familiar e o seguro defeso. Além disso, essa definição na letra da lei pode incentivar a informalidade no setor que deveria ser reconhecido como empresarial, já que são mais capitalizados, possuem mais de uma embarcação e utilizam mão de obra de pescadores que muitas vezes não possuem nenhum instrumento de trabalho próprio, o que caracterizaria uma relação de assalariamento, e não de parceria.

No que diz respeito à participação e aos espaços de interlocução com a sociedade civil envolvida no setor, o governo criou duas instâncias principais: o Conselho Nacional de Pesca (CONAPE), que é um órgão colegiado de caráter consultivo criado em 2003 como parte da estrutura da SEAP, e as chamadas Conferências Nacionais, precedidas por conferências estaduais, que são um mecanismo para aferir as demandas de diferentes segmentos da sociedade civil, neste, como em outros setores. O CONAPE é formado por 54 membros, com 
27 representantes da sociedade civil nomeados a cada dois anos pelas suas assembleias (15 representantes dos movimentos sociais e trabalhadores, 10 representantes da área empresarial, e 02 da área acadêmica e de pesquisa), e com os outros 27 representantes de órgãos governamentais envolvidos com o tema. No período analisado, o CONAPE se reuniu de 2 a 3 vezes por ano, e houve 3 Conferências Nacionais de Pesca e Aquicultura (2003, 2006 e 2009), e uma Conferência das Trabalhadoras da Pesca e da Aquicultura (2004), reunindo estas de 600 a 1500 pessoas.

A criação desses espaços, a proposição de mecanismos de cogestão e a afirmação da participação social como um dos mecanismos da política pesqueira, tanto no texto da nova lei da pesca quanto em vários documentos produzidos pelo MPA apontam para a instituição, ao menos discursivamente, de espaços de participação social. Como aponta Progrebischi (2011), durante o governo Lula, houve um forte impulso à participação social em instâncias consultivas e deliberativas, em especial por meio das Conferências nacionais, sendo que algumas delas se institucionalizaram fortemente. A Conferência Nacional da Pesca e Aquicultura parece não ter alcançado o mesmo grau de institucionalização, uma vez que deveria ter sido realizada novamente em 2011 (sua periodicidade deveria ser bienal), porém até o momento não foi realizada.

Destaca-se, assim, a adoção no âmbito da ideologia governamental de ideias e noções que têm origem tanto nos âmbitos do debate acadêmico como nos movimentos sociais, que engendram uma gramática da participação (Rolnik et al., 2011), como a noção de gestão compartilhada ou cogestão, a economia solidária e a participação social. Essas noções não são neutras e se configuram elas mesmas em objetos de disputa simbólica e ideológica na determinação de seus significados e conteúdos sociais concretos na hora de sua implementação. A demanda por participação social é, por exemplo, ao mesmo tempo uma luta dos movimentos sociais pela democratização da política, por um lado, e por outro faz parte da retórica estabelecida no âmbito dos organismos internacionais impulsionadores da concepção mainstream da governança ambiental.

Já a gestão compartilhada ou cogestão é discutida no âmbito da teoria dos comuns, especialmente sob o enfoque neoinstitucionalista das teorias da ação coletiva (Ostrom, 1990). Dentro dessa literatura, se reconhecem distintos arranjos institucionais que teriam diferentes graus de compartilhamento de poder entre o governo e os usuários no processo decisório (Berkes, 2002). O modelo proposto pelo MPA pode ter a potencialidade de gerar processos mais efetivos de gestão dos recursos pesqueiros, uma vez que se propõe a definir escalas menores e mais apropriadas para a criação das normas, privilegiando a participação dos diversos atores sociais. Pode, se efetivamente implementado, melhorar em alguma medida as condições de vida dos pescadores artesanais, se garantir, além da manutenção da sustentabilidade dos recursos, que a forma de definição das normas lhes favoreçam. Essa condição não está garantida pelo simples estabelecimento de processos de cogestão, pois ao se estabelecer fóruns compostos por atores que têm condições desiguais de poder, e estas não forem contrabalançadas pela flexibilização do peso relativo de cada um dos grupos, pode-se apenas replicar na escala local mecanismos que legitimam o poder das elites. Destacase também que o modelo proposto é consultivo e paritário entre sociedade civil e representantes do governo, se aproximando mais do modelo chamado na literatura referida de corporação multistakeholders (Berkes, 2002), caracterizado pela formação com múltiplos usuários e nível governamental, de caráter consultivo e com o objetivo de estimular a participação pública.

Como destaca Foladori (2002), tem havido um avanço na concepção de sustentabilidade social no que tange à noção de desenvolvimento sustentável, de uma postura que simplesmente associava pobreza a degradação ambiental, para uma em que se propõe a participação na cogestão dos recursos como caminho para atingir a sustentabilidade, mas que não se ocupa de transformar os processos básicos de diferenciação social e repartição desigual da riqueza na sociedade capitalista.

Isso reflete, como pontua Mészáros (2004), que uma igualdade formal em termos da participação política e democrática oculta, por outro lado, uma desigualdade substantiva que tem origem na formação de classes da sociedade capitalista e na diferenciação riqueza - pobreza dentro delas. Ainda assim, o autor destaca que se deve fazer uso da inevitável continuidade no futuro das condições atuais, tendo em vista, porém, a dialética da 
continuidade e descontinuidade, de forma a que as classes subordinadas utilizem estrategicamente as alavancas hoje existentes como elo de mediação para uma ordem social qualitativamente diferente.

Dessa forma, embora a criação desses espaços de participação represente um importante avanço democrático porque neles se podem expressar as demandas populares, por si só não garantem a incorporação dessas demandas às políticas públicas. Mais ainda, a participação nesses espaços, sobretudo quando é numerosa, pode ser usada pelo governo como demonstração de força a favor de alguma intenção própria ou com fins eleitorais visando cativar votos e em todo o caso pode se constituir em legitimação de políticas que não beneficiem às classes populares ou até as prejudiquem.

\section{O foco das políticas: o crescimento econômico privilegia a aquicultura e a pesca industrial oceânica}

Os objetivos da política pesqueira foram reconduzidos pelo governo de forma que o crescimento da produção foi consolidado como principal meta, tal como anuncia o primeiro Projeto Político da SEAP, apresentado após a $1^{\text {a }}$ Conferência Nacional de 2003 (SEAP, 2003), onde, entre os objetivos traçados para serem alcançados até 2006, figuram: o aumento da produção da aquicultura e da pesca em $50 \%$, passando de 1 milhão de toneladas/ano para 1,5 milhão de toneladas/ano; o aumento do consumo per capita de $6,8 \mathrm{~kg} /$ habitante/ano para $12 \mathrm{~kg} /$ habitante/ ano; o aumento da renda média do produtor/pescador; a modernização da cadeia produtiva da aquicultura e da pesca e a ampliação ordenada de seu parque industrial.

Essa concepção se consagra em 2008, no primeiro plano sistemático para o setor pesqueiro apresentado pela SEAP, intitulado Mais Pesca e Aquicultura (SEAP. 2008a). Nesse, figuram como objetivos centrais "recuperar estoques pesqueiros na costa brasileira e nas águas continentais, desenvolver a pesca oceânica e o grande potencial da aquicultura brasileira em águas da União e em estabelecimentos rurais" (grifos das autoras) (SEAP, 2008a, p.08). O caminho para atingir tal objetivo, de acordo com a SEAP, seria a estruturação da cadeia produtiva.
Assim, reconhecendo que a maior parte dos estoques pesqueiros das áreas costeiras está sobre-explotada, e sem pôr os devidos esforços em reverter essa situação - fundamental para a reprodução da pesca artesanal - o governo decidiu incentivar a produção da pesca industrial oceânica sob o suposto de que nas águas profundas ainda haveria margem para incrementar a produção. Essa concepção, contudo, não se mostrava condizente com as conclusões apresentadas na Avaliação do Potencial Sustentável dos Recursos Vivos na Zona Econômica Exclusiva do Programa ReviZEE (MMA, 2006), que indicou o baixo potencial de exploração sustentável desses recursos. Um grupo de pesquisadores, muito dos quais participantes das pesquisas ligadas ao ReviZEE (Rossi-Wongtschowski et al., 2004), emitiram um documento produzido coletivamente intitulado "Uma contribuição para a gestão da pesca no Brasil" questionando as medidas adotadas pelo MPA.

Desta forma, dentro da pesca extrativa, o governo estabeleceu como principais atores para protagonizar o pretendido crescimento os empreendedores da pesca industrial. Para gerar esse crescimento, o governo desenvolveu vários programas de ação. Um deles é o Programa Sustentável de Modernização da Frota Pesqueira Nacional - Programa Profrota, que consistia em uma política de crédito para fabricar barcos visando constituir uma frota nacional para atuar na Zona Econômica Exclusiva (ZEE) brasileira, com expectativas de incrementar a pesca de espécies como os grandes atuns e similares (SEAP, 2008b). Essa frota nacional iria substituir as embarcações estrangeiras que estavam sendo arrendadas e traria para o país recursos que também estavam sendo apropriados por frotas estrangeiras. Vale ressaltar que, além disso, o Profrota visava providenciar fundos para a substituição de embarcações de pesca industrial que operam sobre os estoques costeiros de camarão, pargo (Lutjanus purpureus poey) e piramutaba (Branchplatystoma vaillant), condicionado a que as embarcações mais antigas fossem inabilitadas. O programa, contudo, não obteve o sucesso desejado pelo governo: apenas oito embarcações das 130 planejadas foram financiadas.

Além disso, a pesca industrial foi beneficiada com o incremento paulatino do Programa de Subvenção ao Óleo Diesel, o combustível usado pelas embarcações, que, mais adiante, o governo pretendeu estender aos 
pescadores artesanais, mas que foi limitado por dificuldades operacionais (MPA, 2010a). Segundo dados do Ministério do Planejamento (MPOG, 2009) e do MPA, entre os anos de 2003 e 2010 foram subsidiados 686,7 milhões de litros de óleo diesel, num aporte que totalizou no período R $\$ 145.408 .548,35$, conforme se pode observar na Tabela 1. Pode-se dizer, assim, que esse programa atende principalmente à pesca industrial, contribuindo $\mathrm{a}$ tornar economicamente viáveis pescarias que não o são do ponto de vista ecológico. Destaca-se também que os subsídios influenciam no preço do pescado, causando desvantagem comparativa aos pescadores que não os recebem.

TABELA 1 - Subsídios ao óleo diesel no período de 2003 a 2010. Valores em Reais.

\begin{tabular}{cc}
\hline Ano & Valor Pago \\
\hline 2003 & $4.033 .961,25$ \\
2004 & $9.944 .710,91$ \\
2005 & $8.556 .980,34$ \\
2006 & $25.172 .319,88$ \\
2007 & $30.054 .889,05$ \\
2008 & $24.700 .202,94$ \\
2009 & $23.158 .119,82$ \\
2010 & $19.787 .364,16$ \\
\hline Total & $\mathbf{1 4 5 . 4 0 8 . 5 4 8 , 3 5}$ \\
\hline
\end{tabular}

FONTE: As autoras a partir de dados do Ministério do Planejamento, Orçamento e Gestão (MPOG, 2009) e do Ministério da Pesca e Aquicultura (2010a). Valores corrigidos pelo IPC-A para 12/2010.

Os subsídios à pesca industrial estão entre as medidas mais criticadas pelos cientistas pesqueiros e ecologistas (Sumaila et al., 2010), pois possibilitariam a continuidade da atividade mesmo quando o nível de exploração dos estoques está comprometido. Dentro do debate internacional sobre o tema, há autores que consideram esse tipo de subvenção como maus subsídios, como Sumaila e Pauly (2006). Para a FAO (2003), porém, é necessário identificar como os subsídios se articulam com as medidas de gestão e como o conjunto de incentivos altera o comportamento do setor, inferindo que além dos subsídios, outros fatores são levados em consideração pelos pescadores e indústria na tomada de decisão em relação à atividade. Esse debate tende a levar em conta especialmente os aspectos econômicos e ecológicos, ficando a sustentabilidade social à margem do debate.

A expansão do crédito para o setor pesqueiro também tem sido uma ação prioritária do governo, e se consolidou com o lançamento do $1^{\circ}$ Plano Safra das Águas, em 2010 (MPA, 2009a). Criaram-se novas linhas de crédito e ampliaram-se os limites para a pesca industrial e para a aquicultura. Por outro lado, ampliou-se a inclusão de pescadores artesanais no Programa Nacional da Agricultura Familiar (PRONAF), mas que ainda possui muitos limites e problemas na execução, como baixos valores financiáveis tendo-se em vista o custo dos petrechos de pesca e dificuldade de operacionalização junto aos agentes financeiros que operam o programa. $\mathrm{O}$ acesso ao crédito é demanda e medida importante para a pesca artesanal, mas sem um necessário acompanhamento de medidas de gestão eficientes pode torná-las prejudiciais à própria pesca artesanal.

TABELA 2 - Número de contratados e valores aplicados na política de crédito ao setor pesqueiro entre 2003 e 2010 . Valores em reais.

\begin{tabular}{ccc}
\hline Ano & Contratos & Montantes \\
\hline 2003 & 14.509 & $151.114 .688,07$ \\
2004 & 31.679 & $277.123 .848,73$ \\
2005 & 34.655 & $207.854 .579,39$ \\
2006 & 36.375 & $212.685 .898,67$ \\
2007 & 29.816 & $195.761 .341,62$ \\
2008 & 21.830 & $206.575 .106,36$ \\
2009 & 21.016 & $234.018 .368,96$ \\
2010 & 22.782 & $259.976 .763,00$ \\
\hline Total & $\mathbf{2 1 2 . 6 6 2}$ & $\mathbf{1 . 7 4 5 . 1 1 0 . 5 9 4 , 8 0}$ \\
\hline
\end{tabular}

FONTE: As autoras a partir de dados fornecidos pela Coordenação de Crédito do Ministério da Pesca e Aquicultura à autora (Comunicação Pessoal, 2010). Valores corrigidos pelo IPC-A para 12/2010.

Os dados disponibilizados sobre crédito pelo MPA apontam um montante de $\mathrm{R} \$ 1.745 .110 .594,80$ aplicados entre os anos de 2003 e 2010, num total de 212.662 contratos (Tabela 2). Mas esses dados não diferenciam os beneficiários de forma que não se sabe quanto foi destinado a cada subsetor pesqueiro nem o que foi destinado à aquisição de petrechos de pesca, embarcações e/ou motores.

Já em relação à aquicultura, o governo lhe foi atribuindo cada vez mais importância, de forma que quando 
o MPA venceu os entraves dos órgãos ambientais e trouxe para si a atribuição do ordenamento aquícola passou a realizar a demarcação de Parques Aquícolas, bem como o desenvolvimento de Planos Locais de Desenvolvimento da Maricultura (PLDM) (SEAP, 2005a). Segundo o MPA (2010a), 42 parques aquícolas continentais já estão em funcionamento, em 6 reservatórios: Itaipu (PR), Castanhão (CE), Ilha Solteira (MS, MG e SP), Furnas (MG), Três Marias (MG) e Tucuruí (PA). Os estados para os quais estão sendo desenvolvidos os PLDMs são: Santa Catarina, Paraná, Maranhão, Pará, Ceará, Espírito Santo, Rio Grande do Norte, Sergipe, Bahia, São Paulo, Pernambuco, Rio de Janeiro e Rio Grande do Sul. A partir de então, a aquicultura passou a ser o subsetor principal para o fim do crescimento produtivo, e, portanto, o mais privilegiado pela política governamental. Assim, o MPA vem fazendo cessões onerosas e não onerosas de áreas aquícolas. Por outro lado, se propõe a integração vertical da cadeia produtiva, por meio do desenvolvimento e adoção de pacotes tecnológicos (Sabanay, 2011).

Apesar da porção de espaços aquícolas cedida de forma não onerosa, cujo público alvo seria composto pelos pequenos produtores ou pescadores artesanais, esta política implica o início de um processo de valorização primária (Altvater, 2010) e de privatização dos espaços aquáticos continentais e marinhos que, sem dúvida, conflita, principalmente, com a pesca artesanal, pois dispõe das áreas onde ela normalmente acontece. $\mathrm{O}$ reconhecimento dessa potencialidade de conflitos entre pesca artesanal e aquicultura não figura nos discursos do governo, e ainda, apontam que graças a sua ajuda - com cessões não onerosas e capacitação - virarão aquicultores, e assim resolverão os limites impostos pela crise de recursos e melhorarão definitivamente sua renda e suas condições de vida. A aquicultura é, pois, o projeto principal de desenvolvimento pesqueiro deste governo, e o futuro programado para o pescador artesanal é que deixe de pescar, isto é, que deixe de ser pescador.
É importante destacar que, apesar do anterior, desde o início da atuação da SEAP existe, no discurso governamental, a proposição de atender prioritariamente a pesca artesanal. Os dados da distribuição orçamentária da SEAP entre os anos 2003 e 2009 a primeira vista parecem confirmar essa intenção.

Observando a Tabela 3, os números absolutos mostram que a pesca artesanal recebeu a maior quantidade dos gastos/investimentos (36\%), seguida pelo setor industrial, que recebeu $26 \%$ do total, e a aquicultura que recebeu apenas $14 \%$, sendo o $24 \%$ restante dos gastos destinados à administração e publicidade. Porém, ao se considerar a quantidade de pessoas de cada setor, que são as reais beneficiárias desses gastos, o sentido da distribuição se inverte, mostrando que os 700.000 pescadores artesanais do país ${ }^{3}$ receberam relativamente muito menos que os empresários industriais e armadores, que são uns poucos milhares, considerando que há aproximadamente 1600 embarcações neste subsetor ${ }^{4}$. Por sua vez, considerando ainda o caráter incipiente da aquicultura no país, o montante destinado a esta também tem um peso relativo maior. Mas, aos efeitos de nossa questão, o relevante é que esses números ratificam que, apesar do discurso, os pescadores artesanais não são os beneficiários principais do apoio do governo ao setor pesqueiro, considerando os investimentos feitos com recursos próprios do órgão criado com a finalidade de instituir políticas para o setor.

TABELA 3 - Distribuição do orçamento da SEAP (2003-2009).

\begin{tabular}{ccc}
\hline Setor & Investimento (R\$) & $\mathbf{\%}$ \\
\hline Pesca artesanal & $\mathrm{R} \$ 257.570 .000,00$ & 36 \\
$\begin{array}{c}\text { Pesca industrial (inclui Profrota } \\
\text { e subvenção ao óleo diesel) }\end{array}$ & $\mathrm{R} \$ 191.600 .000,00$ & 26 \\
$\begin{array}{c}\text { Aquicultura } \\
\text { Outros: Publicidade e } \\
\text { Administrativo }\end{array}$ & $\mathrm{R} \$ 102.450 .000,00$ & 14 \\
\hline Total Geral & $\mathrm{R} \$ 171.166 .000,00$ & 24 \\
\hline R\$ 722.786.000,00 & $\mathbf{1 0 0}$ \\
\hline
\end{tabular}

FONTE: As autoras, com base em dados do Ministério da Pesca e Aquicultura (MPA, 2009b). Valores não corrigidos.

\footnotetext{
${ }^{3}$ Dados apresentados por Vasconcellos et al. (2007) apontavam que mais de 50\% da pesca extrativa do país tem origem na pesca artesanal. Contudo, nas últimas estatísticas apresentadas pelo MPA não há diferenciação entre a produção da pesca industrial e artesanal, figurando apenas como pesca extrativa. Reconhece-se, porém, a importância fundamental da pesca artesanal na segurança alimentar, importância reafirmada recentemente pela FAO com a aprovação das Diretrizes voluntárias para a Pesca Artesanal em junho de 2014.

${ }^{4}$ Segundo dados do Programa de Rastreamento das Embarcações por Satélite.
} 
Além disso, os documentos apresentados pelo MPA à Controladoria Geral da União (CGU), as Prestações de Contas do Presidente da Repúbica (PCPRs) (Brasil, 2009f; Brasil 2010; Brasil, 2011) permitem observar a evolução dos gastos segundo as funções do órgão (Figura 1). Ao se observar as informações prestadas relativo ao ano de exercício 2010 (Brasil, 2011), se pode verificar a prioridade dada pelo ministério ao fomento da cadeia produtiva. Conforme consta no referido documento, para o ano de 2010 mais de 50\% da dotação orçamentária do MPA foi destinada a função promoção da produção animal, enquanto os gastos em normatização e fiscalização ficaram em torno $5 \%$.

Tendo-se em vista que, segundo o apontado pelo próprio MPA em seu Plano Mais Pesca e Aquicultura (SEAP, 2008a), a recuperação dos estoques pesqueiros é um dos objetivos principais da política, pode-se dizer que a atuação do MPA não tem sido consistente para alcançar tal objetivo, uma vez que privilegia a transformação e a produção, e a recuperação dos estoques depende diretamente das ações de ordenamento pesqueiro e da fiscalização da atividade. Ou seja, dentro do orçamento total do MPA, apenas uma pequena parte se destina ao ordenamento e gestão da pesca, sendo a maior parte destinada à cadeia produtiva. É certo que os recursos para a gestão e ordenamento podem ter origem também em outros Ministérios, como o MMA, mas ao se propor a ser um órgão que controla toda a gestão e ordenamento da pesca e aquicultura é significativo o privilégio dado ao fomento em detrimento do ordenamento e gestão, em termos de investimentos.

Nesse aspecto, cabe destacar que os pescadores artesanais são particularmente atingidos pela crise dos recursos, haja vista a sua menor capacidade de reconversão de atividade e de busca de pescado em outras áreas de pesca, se comparado ao setor industrial. Assim, a baixa prioridade dada pelo MPA ao ordenamento e a fiscalização podem afetar mais danosamente à pesca artesanal.

Há que se destacar, contudo, que, embora permeado por estas contradições, as políticas desenvolvidas pelo MPA buscam, em alguma medida, atender a determinadas demandas do setor pesqueiro artesanal, o que até então havia estado fora ou colocado apenas marginalmente nas políticas desenvolvidas anteriormente como será visto a seguir.

\section{As ações dirigidas à pesca artesanal: o alívio imediato da pobreza em detrimento de seu fortalecimento de longo prazo}

Mas, qual é a política do governo atual para a pesca artesanal em si? A maior parte das ações realizadas pelo MPA destinadas à pesca artesanal estava focada na redução de custos, diminuição da dependência do atravessador e retenção de maior renda. Começando com

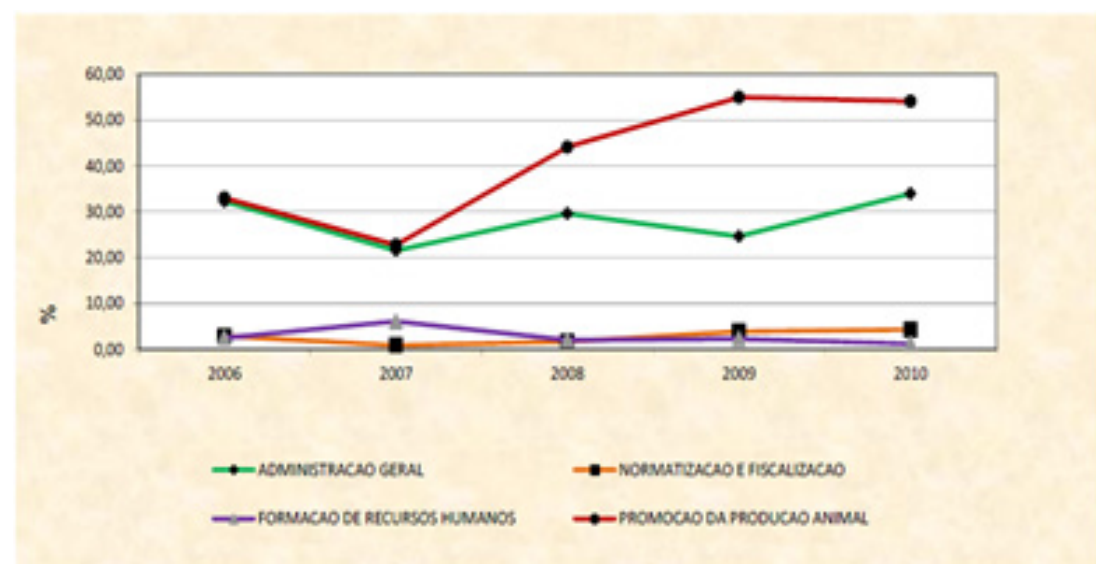

FIGURA 1 - Evolução dos gastos do MPA por subfunção de governo - 2006 - 2010.

FONTE: Prestação de Contas do Presidente da República à Controladoria Geral da União, Brasil, 2010 . 
as ações voltadas para a atividade pesqueira, a principal medida do governo orientada à fase de produção da pesca artesanal foi a ampliação já referida do acesso dos pescadores artesanais ao crédito oriundo do PRONAF. Além disso, desenvolveu um programa específico para a melhoria das embarcações da pesca artesanal, o Programa de Revitalização da Frota Pesqueira Artesanal - Revitaliza, criado em 2010 (MPA, 2010b). Este tinha como objetivos promover a reforma e modernização, prover recursos para finalização da construção e substituir algumas embarcações de pequeno porte.

A proposta desses financiamentos era que, mesmo melhorando a embarcação de forma a permitir mais segurança para o pescador e melhores condições de trabalho e de acondicionamento do pescado esses não produzissem aumento no esforço de pesca de espécies controladas. Não se obteve acesso aos dados sobre a implementação do programa, mas sabe-se que alguns equipamentos financiados podem resultar no aumento do poder de pesca das embarcações. Esse resultado só poderia ser evidenciado com análise dos dados sobre os equipamentos financiados.

Outras ações referentes à fase produtiva foram dirigidas a diminuir custos de insumos, tais como a distribuição de fábricas de gelo e o acesso à subvenção ao óleo diesel. Como já citado, esta subvenção tem atendido prioritariamente à pesca industrial, uma vez que há dificuldades de operacionalizar o sistema para a pesca artesanal, devido a questões como o grande número de pontos de desembarque, a pulverização espacial da pesca artesanal e a dependência do sistema colônias, entre outros. Em relação às fábricas de gelo, segundo o MPA (2010a), até o ano de 2010 foram entregues 133 unidades. Dificuldades relatadas em relação à operação referem-se a problemas na gestão por falta de capacitação, alto custo da energia elétrica, falta de rede trifásica, problemas na regularização dos terrenos, má qualidade de algumas unidades entregues e falta de assistência técnica para reparos, entre outros. Cabe destacar que, assim como em quase todas outras ações de apoio à cadeia produtiva, as ações em geral são programadas para atender tanto a pesca artesanal quanto à aquicultura familiar, sendo difícil identificar os beneficiários.

Outras medidas foram orientadas a otimizar as fases pós-captura da cadeia produtiva da pesca, isto é o processamento e a comercialização. Entre estas figuram ações de apoio a pequenos empreendimentos da pesca artesanal, com fornecimento de cozinhas comunitárias, kits de manipulação de mariscos, pontos comerciais fixos e acampamentos para pescadores. Os chamados kits feira do peixe também foram cedidos a pescadores artesanais e aquicultores, totalizando 640 entre os anos de 2006 e 2010. Registram-se também investimentos na construção de Unidades de Beneficiamento do Pescado, com 35 programadas, também destinadas tanto a pescadores quanto aquicultores (MPA, 2010a).

Igualmente foram concedidos caminhões frigoríficos a entidades da administração pública e a entidades sem fins lucrativos, num total de 116 até o ano de 2011. Somam-se ainda 50 caminhões feira do peixe, com estrutura para comercialização ao consumidor, destinados a municípios com mais de 120 mil habitantes ou a consórcios municipais (MPA, 2010a). Por último, na fase do consumo, o governo incluiu o pescado no Programa de Aquisição de Alimentos da Agricultura Familiar, tanto nas ações do Programa Fome Zero quanto no Programa Nacional de Alimentação Escolar, como meio de ampliar e garantir um mercado consumidor regular, assim como certos preços (SEAP, 2008c).

A proposta mais abrangente de apoio à cadeia produtiva da pesca artesanal formulada pelo MPA durante o período foram os Centros Integrados da Pesca artesanal (CIPARs), que consistiriam em estruturas de pequeno e médio porte que teriam como função articular regionalmente as políticas públicas empreendidas pelo ministério dirigidas à pesca artesanal. Previam-se investimentos na infraestrutura da cadeia produtiva (píer para atracação de embarcações, fábricas de gelo, estrutura para beneficiamento do pescado, etc.), além de espaços para ensino e qualificação profissional e ainda, apoio à autogestão de empreendimentos e gestão compartilhada e ordenamento pesqueiro local. Até 2010, estavam previstos a construção de 8 CIPARs, contudo até 2012 apenas um estava em fase de conclusão e implementação (MPA, 2010a), o que demonstra a baixa capacidade de execução do programa.

É pertinente destacar que inicialmente, esses equipamentos eram concedidos por demanda, e não via chamada pública para seleção. Posteriormente, o MPA adotou as chamadas públicas como forma de realizar as 
concessões, além de incluir propostas de processos de formação para a autogestão dos empreendimentos em seus editais.

Outro aspecto relevante é que em 2009 foi formulada a Política Territorial da Pesca e Aquicultura, com a seleção de 62 territórios iniciais para participação (SEAP, 2008d). Entre as propostas criadas para a política territorial estava a formação de um Colegiado e a construção de Planos Locais de Desenvolvimento da Pesca e Aquicultura, baseados nos modelos dos Territórios Rurais e Territórios da Cidadania. Além disso, a existência dos territórios servia como um critério para a alocação dos recursos do MPA, uma vez que seriam priorizadas as propostas participantes nos editais que estivessem inseridas nos territórios. Durante a participação no I Encontro dos Territórios em 2010 em Itajaí verificou-se que até então nenhum dos territórios havia concluído o Plano de Desenvolvimento. Após esse período, a política sofreu contingenciamento orçamentário, e não ocorreram mais ações nacionais referentes à política.

Em 2008, foi lançado o Plano Nacional de Assistência Técnica e Extensão Pesqueira (ATEPA) (SEAP, 2008e), que tem como objetivo geral promover e apoiar iniciativas de desenvolvimento local sustentável e solidário visando a inclusão social e a melhoria da qualidade de vida das comunidades pesqueiras e aquícolas, adotando os princípios da agroecologia como eixo orientador das ações. Entre seus objetivos específicos constam: a adoção gradual de sistemas de produção em aquicultura; a melhoria da renda e geração de trabalho "em equilíbrio com o meio ambiente" o estímulo à participação política dos pescadores; a promoção de ações integradas de inclusão social que garantam o acesso às políticas públicas; facilitação do acesso e qualificação da elaboração e execução de projetos de crédito; estímulo às formas de beneficiamento e comercialização do pescado; desenvolvimento de ações que promovam boas práticas ao longo da cadeia produtiva; geração de novas fontes de renda de forma não subordinada; incentivo a experiências participativas de manejo pesqueiro, e o estímulo ao associativismo e cooperativismo popular de autogestão, participativo e solidário, fortalecendo assim a capacidade de intervenção coletiva dos pescadores artesanais e aquicultores familiares proporcionando melhores condições de competitividade, gerando laços de solidariedade e, dessa forma, contribuindo para o desenvolvimento "homogêneo e sustentável" das comunidades (SEAP, 2008e).

As ações de ATEPA têm sido selecionadas via chamadas públicas, com a participação de organizações não governamentais e entidades públicas, e totalizaram até 2010, segundo o MPA (2010a) 122 convênios. Destaca-se que a retomada da ATEPA (que havia se tornado incipiente desde a extinção da Sudepe) se deu, por um lado, superando o discurso difusionista e modernizante que existia no período da Sudepe, (Callou, 2006) por um lado, e por outro, num contexto de baixa capacidade de ação estatal, o que leva a construção de parcerias com ONGs, que geram entraves na continuidade das ações.

Ocorreram também outras iniciativas em matéria educativa, tais como um programa de alfabetização (Pescando Letras) e cursos técnicos em pesca e em aquicultura, com conteúdos e formas pedagógicas desenhadas especificamente para pescadores (SEAP, 2005b). Destacam-se também a implantação de Telecentros nas comunidades pesqueiras, os chamados Telecentros Maré. Não existem ainda pesquisas sistemáticas que analisem a implementação de todos esses programas. Em relação ao Programa Pescando Letras, uma análise feita por Araújo (2011) apontou pra o baixo grau de eficácia do programa, sendo que a grande maioria dos pescadores foi inserida em turmas convencionais de alfabetização e a metodologia específica do projeto foi pouco aplicada.

Mas, a mais destacada das ações voltadas à melhoria de renda é a política do chamado "Seguro Desemprego para o Pescador Artesanal", mais conhecido como Seguro Defeso, que consiste no pagamento de um salário mínimo mensal (US\$291, aproximadamente, em valores de dezembro de 2010) aos pescadores artesanais envolvidos na pesca de determinadas espécies durante os períodos em que esta é proibida (de 2 a 6 meses por ano, dependendo da espécie e da região) com o fim de favorecer a reprodução e manutenção dos estoques. Surgida em 1991 como uma ferramenta de gestão pesqueira (Dias Neto, 2010), essa política foi exponencialmente ampliada durante o governo do Presidente Lula. A SEAP facilitou o acesso e não fez os devidos controles, estimulando que recebam esse benefício muitos pescadores que não pescam as espécies em questão, e inclusive muitas pessoas que não são pescadores profissionais, 
frequentemente próximas destes, e que ilicitamente se registram como tais.

Desta forma, essa ferramenta de gestão ambiental, se voltou, pela via dos fatos, uma política social distributiva muito forte, concebida e facilitada pelo Ministério de Pesca, mas financiada pelo Ministério de Trabalho e Emprego, por esse benefício ter sido formulado como um seguro de desemprego. A Figura 2 é eloquente em mostrar o crescimento das pessoas registradas como pescadores profissionais e o crescimento, ainda maior, da quantidade de dinheiro pago como seguro defeso no período 2003-2009. Este crescimento relativo maior de montante pago se deve ao incremento do salário mínimo nacional registrado nesse período (US\$ 77,00 em 2003; US\$ 291,00, em 2010), bem como ao aumento do número de meses de benefício (MPOG, 2009).

Os dados indicam, então, que o objetivo principal da política do governo dirigida para a pesca artesanal busca a redução da pobreza mediante o incremento da renda dos pescadores artesanais e de suas comunidades, em primeira instância, por meio da melhoria da cadeia produtiva e a diminuição da dependência de intermediários. Mas, sendo ambas positivas e necessárias, são limitadas pelo fato de nenhuma dessas medidas terem caráter universal e/ou sistemático. Pelo contrário, se trata de ações focalizadas, fragmentadas, dispersas e pontuais, que são incapazes de transformar significativamente a realidade das comunidades pesqueiras. A concessão desses equipamentos e instrumentos, ainda que importantes para melhoria das condições de comercialização, deveria estar vinculada a uma política clara de desenvolvimento das comunidades pesqueiras.

Considerando isso, e o volume de dinheiro público distribuído como pagamento do seguro defeso a grande parte da categoria, esta medida distributiva se constitui na mais significativa realizada pelo governo com respeito à pesca artesanal no período considerado. Mas, também é limitada, pois se trata de um mecanismo não universal e, ainda, com vícios de procedimento que questionam sua legalidade e, portanto, sua continuidade.

No conjunto, o que predomina como política específica para a pesca artesanal, então, é uma política social de corte distributivo, que, apesar de, no imediato, servir para a diminuição da pobreza e a melhora de qualidade de vida das comunidades pesqueiras, resulta totalmente insuficiente para atender a situação de fragilidade estrutural da pesca artesanal a médio e longo prazo, como seria necessário. Porém, comparativamente com os períodos

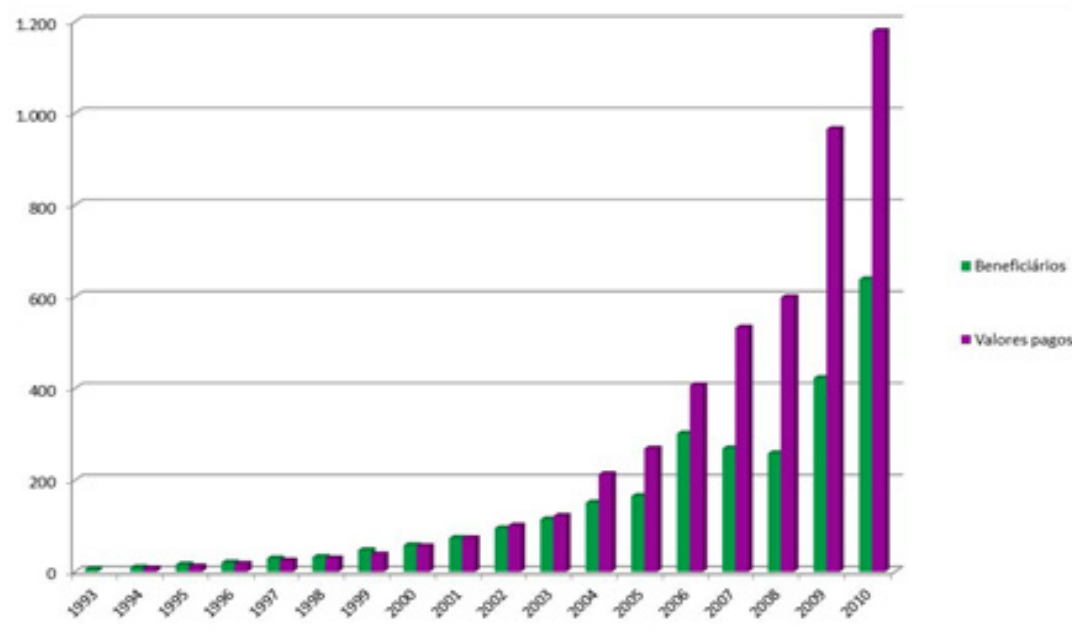

FIGURA 2 - Evolução dos montantes aplicados (R\$) e total de beneficiários do seguro-defeso $1994-2009$.

FONTE: As autoras, com base em MTE, 2010. Valores em Reais - em Milhões, Beneficiários em mil. Valores corrigidos pelo IPC-A para 12/2010. 
anteriores, representam investimentos e reconhecimento das necessidades dos pescadores artesanais que nenhum dos governos empreendeu.

Do ponto de vista das políticas sociais, uma política universalista é aquela que constitui um Estado de Bem-Estar Social, como aponta Esping-Andersen (1991), seria aquela que tende à desmercadorização das formas de satisfazer as necessidades sociais básicas: saúde, educação, habitação, assistência aos idosos, nas quais todos os cidadãos seriam atendidos de forma igual, independente de sua capacidade contributiva. Uma política de corte distributivo, como se tornou o seguro defeso, não pode ser considerada, portanto, uma política universal. Ela depende da continuidade do governo (o que a torna um instrumento eleitoral) e, ainda, não resolve os problemas estruturais e o déficit de acesso a direitos dos quais padecem as comunidades pesqueiras.

No que tange à pesca artesanal, as medidas planejadas pelo próprio MPA que teriam potencial para gerar mudanças substantivas e de longo prazo, como a Política Territorial e os CIPARs, foram contingenciados e sua capacidade de execução muito baixa. Ressalta-se também a necessidade de as ações para a pesca artesanal serem desvinculadas das ações para a aquicultura familiar. Trata-se de subsetores distintos, e o planejamento institucional que os associa inviabiliza uma análise adequada das medidas destinadas à pesca artesanal.

Assim, pode-se concluir em relação à política para a pesca artesanal que ela segue a tendência geral do governo no período, com foco nas medidas distributivas e debilidade nas políticas universalizantes. Não se pode deixar de reconhecer, contudo, que essas medidas distributivas são reconhecidas positivamente pelos beneficiários, e que podem representar uma melhoria nas condições de vida dessas populações, ainda que de forma limitada. Por estar atrelada à inscrição na Previdência Social, atua ainda positivamente no sentido de ampliação da cobertura previdenciária para os pescadores artesanais, já que os estimula ao registro.

\section{Conclusões}

Essas características da política pesqueira atual são condizentes com o modelo de desenvolvimento construído pelo governo federal nos últimos anos, que tem sido denominado de neodesenvolvimentista (Boito Jr., 2012). Este se caracteriza por combinar uma forte atuação governamental para impulsionar o crescimento econômico, principalmente através de grandes obras públicas de infraestrutura e de crédito público outorgado aos agentes econômicos considerados capazes de protagonizá-lo, somada a uma política de distribuição de renda, em grande parte viabilizada mediante benefícios sociais não universais nem permanentes, mas que, no imediato, estimulam o consumo, fortalecem o mercado interno, e criam conformismo nos setores populares. No caso do setor pesqueiro, esse modelo se expressa na prioridade dada à pesca industrial $\mathrm{e}$, crescentemente, à aquicultura, e no caráter predominantemente social, focalizado e distributivo da política voltada à pesca artesanal. Os aspectos ecológicos são os mais negligenciados pela política pesqueira empreendida pelo MPA nesse período.

Grandes projetos de infraestrutura, como represas hidrelétricas, portos e estradas, grandes empreendimentos públicos e privados, como a exploração de petróleo, fazendas de carcinicultura, hotéis resorts, e complexos industriais pressionam cada vez mais aos pescadores artesanais, que não contam com nenhuma proteção especial que lhes garanta a permanência nos seus territórios e a manutenção de seus modos de vida, os elementos centrais e fundamentais para a sobrevivência da pesca artesanal, em face dos conflitos e disputas nos quais estão envolvidos, tanto em terra quanto em mar. A política para o setor pesqueiro não somente não escolhe aos pescadores artesanais como destinatários privilegiados do apoio do governo, senão que a prioridade dada ao crescimento produtivo e a eleição da pesca industrial e da aquicultura implicam, por um lado, o incremento da escassez de recursos pesqueiros, e, por outro, a privatização das águas, que já começou, processos que fragilizam ainda mais a pesca artesanal.

No conjunto, a atuação governamental dos últimos anos, detrás de um discurso de suposta sensibilidade social e responsabilidade ambiental, e apesar da diminuição imediata da pobreza, tem contribuído para aumentar a vulnerabilidade e a situação de injustiça ambiental sofrida pelas comunidades pesqueiras artesanais.

Frente a esta situação, parte significativa dos pescadores artesanais organizados tem adotado uma 
posição crítica ao governo. Em 2010, isto cristalizou na criação de um novo movimento nacional e autônomo da categoria, denominado Movimento de Pescadores e Pescadoras Artesanais do Brasil (MPP). Em 2012, o MPP lançou a Campanha Nacional pela Regularização dos Territórios das Comunidades Tradicionais Pesqueiras, que tem como objetivo principal a aprovação de uma Lei de Iniciativa Popular que reconheça e disponha a demarcação das áreas de terra e água das quais dependem as comunidades pesqueiras (Pierri et al., 2013). O reconhecimento do direito coletivo à esses territórios e aos recursos neles presentes é considerado a condição fundamental para garantir a sustentabilidade da pesca artesanal e garantir a reprodução dos modos de vida e práticas tradicionais de suas comunidades. A luta por conquistá-lo constitui uma exemplar resistência dos pescadores artesanais brasileiros frente ao modelo de desenvolvimento excludente impulsionado pelo governo nos últimos anos.

\section{Referências}

Abdalah, P. R.; Sumaila, U. R. An historical account of Brazilian public policy on fisheries subsidies. Marine Policy, 31, 444-450, 2007.

Abdallah, P. R. Atividade pesqueira no Brasil: política e evolução. Tese (Doutorado em Ciências). Escola Superior de Agricultura Luiz de Queiroz - ESALQ. Universidade de São Paulo, 1998.

Acselrad, H.; Leroy, J. P. Novas premissas da sustentabilidade democrática. Revista Brasileira de Estudos Urbanos e Regionais, 1, 1999.

Acselrad, H. Território, localismo e política de escalas. In: Acselrad, H.; Mello, C. C. A.; Bezerra, G. N. (Orgs.) Cidade, ambiente e política: problematizando a agenda 21 local. Rio de Janeiro: Garamond, 2006, p. 13-32.

Acselrad, H.; Mello, C. C.; Bezerra, G. N. O que é justiça ambiental. Rio de Janeiro: Garamond, 2009.

Altvater, E. O fim do capitalismo como o conhecemos. Rio de Janeiro: Civilização Brasileira, 2010.

Alves, H. P. Metodologias de integração de dados sociodemográficos e ambientais para análise de vulnerabilidade socioambiental em áreas urbanas no contexto das mudanças climáticas, In: Hogan, D. J.; Marandola, E. (Orgs.) População e mudança climática. Dimensões humanas das mudanças ambientais globais. Campinas: NEPO/Unicamp; Brasília: UNFPA, 2009, p.75-105.

Antunes, R. A desertificação neoliberal no Brasil: Collor, FHC e Lula. São Paulo: Editores Associados, 2005.

Araújo, M. F. R. Pescando Letras: diálogos interdisciplinares entre a educação ambiental e a alfabetização de jovens e adul- tos no contexto da pesca artesanal. Dissertação (Mestrado em Desenvolvimento Sustentável). Universidade de Brasília, 2011.

Berkes, F. Cross-scale institutional linkages for commons management: perspectives from the bottom up. In: OSTROM, E. The drama of the commons. Washington: National Academy Press, 2002. p. 293-321.

BNDE - Banco Nacional do Desenvolvimento Econômico. Pesca: aspectos setoriais da atuação do BNDE. Brasília, 1975.

Boito Jr., A. As contradições da frente neodesenvolvimentista. 2012. Disponível em: http://www.viomundo.com.br/politica/ armando-boito-jr-as-contradicoes-da-frente-neodesenvolvimentista.html. Acesso em 04/03/2012.

Brasil. Decreto-lei $n^{\circ} 227$, de 28 de fevereiro de 1967. Disponível em: http://www.planalto.gov.br/ccivil_03/decreto-lei/ del0227.htm Acessado em: 14/07/2014.

Brasil. Instituto Brasileiro do Meio Ambiente e Recursos Naturais Renováveis. Portaria IBAMA $n^{\circ}$ 96, 22 de agosto de 1997. Disponível em: http://www.icmbio.gov.br/cepsul/ images/stories/legislacao/Portaria/1997/p ibama 961997 limitafrotacerco revoga $p \quad 1347 \quad 1989 \quad 1988 \quad 1992$ alterada_in_15_2009.pdf. Acessado em 13/07/2014.

Brasil. Decreto $n^{\circ} 4.895$, de 25 de novembro de 2003. Disponível em: http://www.planalto.gov.br/ccivil_03/decreto/2003/ D4895.htm. Acessado em 15/07/2014.

Brasil. Ministério do Meio Ambiente. Instrução Normativa no. 5 de 21 de maio de 2004. Disponível em: http://www.mma. gov.br/estruturas/179/_arquivos/in_mma_005_04_179.pdf. Acessado em 13/07/2014.

Brasil. Medida Provisória (MP) no. 437, de 29 de julho de 2008. Disponível em: http://www.planalto.gov.br/ccivil_03/ ato2007-2010/2008/Mpv/437.htm. Acessado em: 14/07/2014. 
Brasil. Lei $n^{\circ} 11.958$ de 26 de junho de 2009a. Disponível em: http://www.planalto.gov.br/ccivil_03/_ato2007-2010/2009/lei/ 111958.htm. Acessado em 14/07/2014.

Brasil. Decreto $n^{\circ}$ 6.981, de 13 de outubro de 2009b. Disponível em: http://www.planalto.gov.br/ccivil_03/_Ato20072010/2009/Decreto/D6981.htm. Acessado em: 14/07/2014

Brasil. Ministério da Pesca e Aquicultura, Ministério do Meio Ambiente. Portaria Interministerial MPA/MMA no 2 de 13 de novembro de 2009c. Disponível em: http://www.icmbio.gov. $\mathrm{br} / \mathrm{cepsul} / \mathrm{images} /$ stories/legislacao/Portaria/2009/p_mpa mma_02_2009_regulamentagestaocompartilhada_regulamentar_dec_6981_2009.pdf. Acessado em: 14/07/2014.

Brasil. Conselho Nacional do Meio Ambiente. Resolução $n^{o}$ 413, do Conselho Nacional do Meio Ambiente, de 26 de junho de 2009d. Disponível em: http://www.mma.gov.br/port/ conama/legiabre.cfm?codlegi=608. Acessado em: 12/07/2014.

Brasil. Lei no 11.959, DE 29 de junho de 2009e. Disponível em: http://www.planalto.gov.br/ccivil_03/_ato2007-2010/2009/ Lei/L11959.htm. Acessado em: 15/07/2014.

Brasil. Prestação de Contas do Presidente da República.2009f. Disponível em: http://www.cgu.gov.br/Publicacoes/PrestacaoContasPresidente/2009/Arquivos/5126.pdf. Acessado em: $11 / 07 / 2014$.

Brasil. Prestação de Contas do Presidente da República. 2010. http://www.cgu.gov.br/Publicacoes/PrestacaoContasPresidente/2010/Arquivos/5.1.26.pdf. Acessado em: 11/07/2014.

Brasil. Prestação de Contas do Presidente da República.2011. Disponível em: http://www.cgu.gov.br/Publicacoes/PrestacaoContasPresidente/2011/Arquivos/Parte-IV/4.2.2.pdf. Acessado em: 11/07/2014.

Callou, A. B. Extensão rural e desenvolvimento local: significados contemporâneos. Unirevista, 1(3), s/p, 2006.

Clausen, R. E; Clark, B. The Metabolic Rift and Marine Ecology: An Analysis of the Ocean Crisis Within Capitalist Production. Organization Environment, 18(4), 422-444, 2005.

Delgado, G. Capital financeiro e agricultura no Brasil. São Paulo: ICONE Unicamp, 1985.

Dias Neto, J. Gestão do uso dos recursos pesqueiros no Brasil. Brasília: Ibama, 2003.

Dias Neto, J. Pesca no Brasil e seus aspectos institucionais um registro para o futuro. Revista CEPSUL - Biodiversidade e Conservação Marinha, 1(1), 66-80, 2010.

Diegues, A. C. Pescadores, camponeses e trabalhadores do mar. São Paulo: Ática, 1983.
Diegues, A. C. S. A pesca artesanal no litoral brasileiro: cenários e estratégias para sua sobrevivência. Revista Proposta - Experiências em Educação Popular, n. 38 - Pescadores Artesanais, entre o passado e o futuro. Rio de Janeiro. Editora da FASE. 1988.

Esping-Andersen, G. As três economias políticas do welfare state. Lua Nova, 24, 1991.

FAO. Report of the Expert Consultation on Identifying, Assessing and Reporting on Subsidies in the Fishing Industry. Rome, 3-6 December 2002. FAO Fisheries Report. No. 698. Rome, FAO. 2003. 81p.

FAO Brasil. Revisão do marco institucional, da estrutura institucional e organizacional da SEAP/PR. Fortalecimento Institucional da Secretaria Especial de Aquicultura e Pesca SEAP/PR. Brasília, Março/2006.

FAO. Organización de las Naciones Unidas para a Agricultura y la Alimentación. Asegurar la sostenibilidad de la pesca a pequeña escala: unir la pesca responsable y el desarrollo social. Departamento de Pesca y Acuicultura, COFI-Comité de Pesca. Roma, 2009.

Foladori, G. Limites do desenvolvimento sustentável. São Paulo: Imprensa Oficial- Editora da Unicamp, 2001a.

Foladori, G. Tipología del pensamiento ambientalista In: Pierri, N.; Foladori, G. (Orgs.) Sustentabilidad? Desacuerdos sobre el desarrollo sustentable. Montevideo: Trabajo y Capital, 2001b, v. 1, p. 197-230.

Foladori, G. Avanços e limites da sustentabilidade social. Revista paranaense de desenvolvimento, 102, 2002.

Furtado, C. O Brasil pós-milagre. São Paulo: Paz e Terra, 1982.

Giulietti, N.; Assumpção, R. Indústria Pesqueira no Brasil. Revista Agricultura em São Paulo, 42(2), 95-127, 1995.

Hofling, E. M. Estado e políticas (públicas) sociais. Caderno CEDES, 21(55), 2001.

IBAMA - Instituto Brasileiro do Meio Ambiente e Recursos Naturais Renováveis. Plano de gestão para o uso sustentável da sardinha-verdadeira. Brasília, 2011.

Maneschy, M. C. Dabbling in change: the recent institucional changes in the Brasilian fisheries sector have several implications. Samudra, 22 abr., 12-15, 1999.

Mészáros, I. O poder da ideologia. São Paulo: Boitempo, 2004. MMA - Ministério do Meio Ambiente. Avaliação do Potencial Sustentável de Recursos Vivos na Zona Econômica Exclusiva. 
Relatório Executivo. Brasília: 2006. Disponível em: http:// www.mma.gov.br/estruturas/revizee/_arquivos/rel_executivo_revizee.pdf. Acessado em 10/07/2014.

MPA - Ministério da Pesca e Aquicultura. Plano Safra das Águas - 2010 - 2011. Brasília, 2009a.

MPA - Ministério da Pesca e Aquicultura. Balanço geral das ações executadas: 2003-2009. 2009b. 34 slides, color.

MPA - Ministério da Pesca e Aquicultura. Relatório de Ações Executadas no periodo de 2003 a 2010. Secretaria de Infraestrutura e Fomento. Brasília, julho/2010a, 97 pags.

MPA - Ministério da Pesca e Aquicultura. Revitalização da frota pesqueira artesanal. Folder. 4pg. 2010b.

MPOG - Ministério do Planejamento, Orçamento e Gestão. Relatório de avaliação da Secretaria Especial de Aquicultura e Pesca. Brasília, 2009.

MTE - Ministério do Trabalho e Emprego. Políticas públicas de emprego no Brasil: avaliação externa do Programa Seguro-desemprego. Brasília, 2010.

Ostrom, E. Governing the Commons: the Evolution of Institutions for Collective Action. Cambridge University Press, 1990.

Paiva, M. P. Administração pesqueira no Brasil. Rio de Janeiro: Interciência, 2004.

Pierri, N. El proceso histórico y teórico que conduce a la propuesta de desarrollo sustentable. In: Pierri, N.; Foladori, G. (Org.) Sustentabilidad? Desacuerdos sobre el desarrollo sustentable. Montevideu: Trabajo e Capital, 2001, p. 27-79.

Pierri, N.; Azevedo, N. T.; Mesquita, B. Staking Claims: Artisanal fishworkers of Brazil mobilize. Samudra Report, 1, 8-12, 2013.

Progrebischi, T. Participação social como método democrático de gestão. Led Análises, 1, 6-11, 2011.

Rolnik, R.; Klintowitz, D.; Iacovini, R. F. G. Financiamento e processos decisórios: em busca das determinantes da política de desenvolvimento urbano no Brasil. In: $35^{\circ}$ Encontro Anual da Anpocs. Grupo de Trabalho 29 - Processos decisórios e formulação de políticas públicas. Caxambu, 2011. Disponível em: http://www.anpocs.org.br/portal/35_encontro_gt/GT29/ Rolnik_Klintowitz_Iacovini.pdf Acessado em: 10/07/2014

Rossi-Wongtschowski, C.; Perez, J. A. A.; Pezzuto, P. R.; Jablonski, S.; Castello, J. P.; Haimovici, M.; Madureira, L.; Vooren, C. M.; Ávila da Silva, A. O.; Cergole M. C. Uma contribuição para a gestão da pesca no Brasil. 2004. Dispo- nível em: <http://www.doc.ufes.br/agnaldo/pesca/TEXTO-3. pdf $>$. Acessado em 20/07/2014.

Sabanay, L. O BNDES e o Ministério da Pesca. Diário Comércio, Indústria e Serviços, 11 abril 2011. Disponível em: http:// www.dci.com.br/-o-bndes-e-o-ministerio-da-pesca-id252504. html. Acesso em: 12/12/2011.

SEAP - Secretaria Especial de Aquicultura e Pesca. Caderno de Resoluções da $1^{a}$ Conferência Nacional de Aquicultura e Pesca. Brasília, 2003.

SEAP - Secretaria Especial de Aquicultura e Pesca. Programa Nacional de Desenvolvimento da Maricultura em Águas da União. Brasília, 2005a.

SEAP - Secretaria Especial de Aquicultura e Pesca. Programa Pescando Letras. Brasília, 2005b.

SEAP - Secretaria Especial de Aquicultura e Pesca. Mais Pesca e Aquicultura - Plano de Desenvolvimento Sustentável: uma rede de ações para o fortalecimento do setor. Brasília, 2008a.

SEAP - Secretaria Especial de Aquicultura e Pesca. Profrota Pesqueira: Programa Sustentável de Modernização da Frota Pesqueira Nacional. 2008b. 26 slides, color.

SEAP - Secretaria Especial de Aquicultura e Pesca. Inclusão do Pescado na Alimentação Escolar: avaliação e perspectivas. Brasília, 2008c.

SEAP - Secretaria Especial de Aquicultura e Pesca. Política de Desenvolvimento Territorial da Pesca e Aquicultura. 2008d. 13 slides, color.

SEAP - Secretaria Especial de Aquicultura e Pesca. Plano Nacional de Extensão Pesqueira e Aquícola. Brasília, 2008e.

Sumaila, U. R.; Pauly, D. Catching more bait: a bottom up re-estimation of global fisheries subsidies. Research report, vol. 14, no 6. Fisheries Centre, University of British Columbia, 2006.

Sumaila, U. R.; Teh, L.; Watson, R.; Munro, R. A bottom-up re-estimation of global fisheries subsidies. Journal of Bioeconomics, 12, 201-225, 2010.

Therborn, G. ¿Cómo domina la clase dominante? Aparatos del Estado y poder estatal en el feudalismo, el capitalismo y el socialismo. 4ª Ed. México, D. F.: Siglo XXI, 1989.

Vasconcellos, M.; Diegues, A. C.; Sales, R. R. de. Limites e possibilidades na gestão da pesca artesanal costeira. In: Costa, A. L. (Org.) Nas redes da pesca artesanal. Brasília: IBAMA, p. 2-70, 2007. 